\title{
II卷 199
}

る雜雜す究術いウら當會設一の

種利了加上一工出時息せ八、今 にのに・の唘去版メ博ら六メや 關研難 ラ價告ーさン物示ン”。

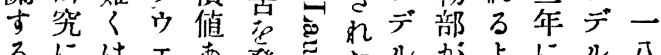

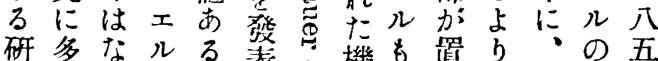

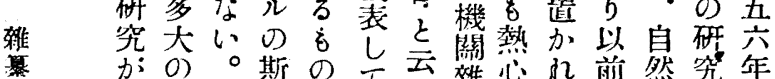

出關後ので居今誌にてに研時か

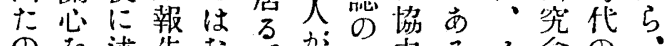

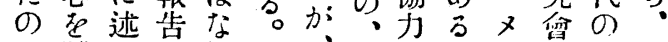

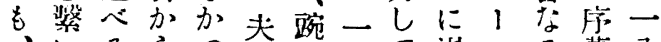

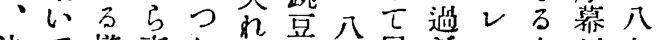
沚で核通たは芨五居きンもが し居な接か＼cjkstart極ひ苍たな|の開一 てた關七:め連年のがか年 偶の係ン㶧宁理度でつシ・れの 然でかれ簡薭刊あたュメた十

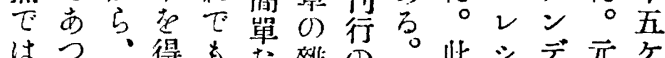

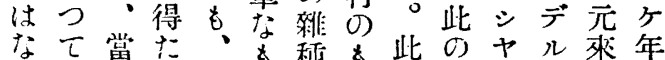

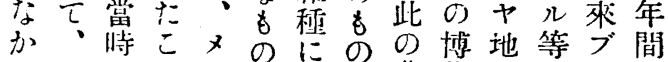

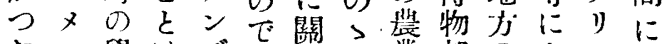

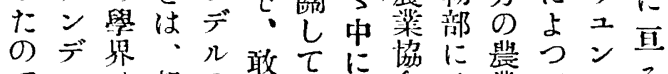
でルは想の敢てに篔は䎼てにる

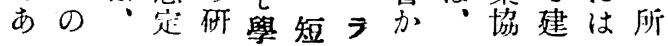

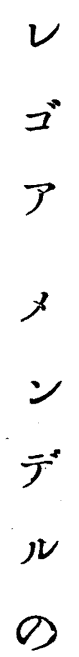

傳

學に生あ人㲦ののたン研二るの

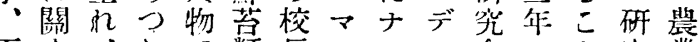

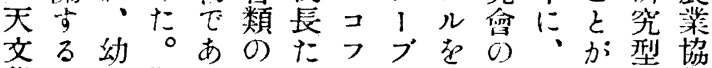
研上斯り研了不始濫一出式會

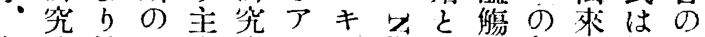
氣論植人菜家ウ1究しで新な依博

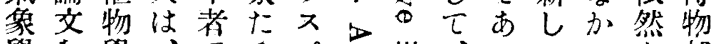

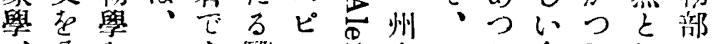

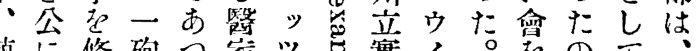

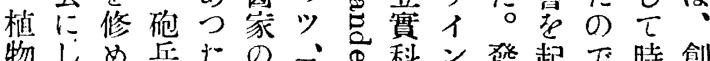
物しめ兵たの发焉學留起し起で時創

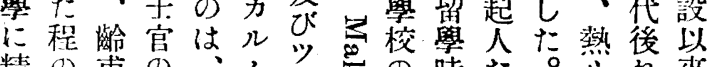

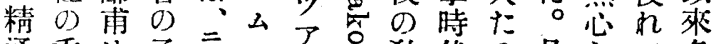

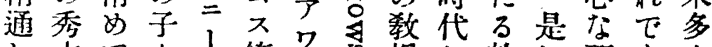

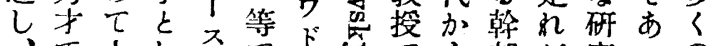

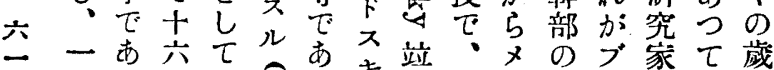

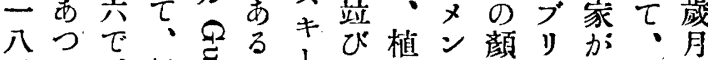

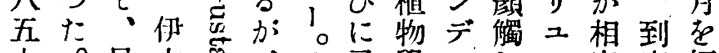
九。早太密・メ已學ルれン寄底經 年飞〈利, 殊 1 述者の存に方過

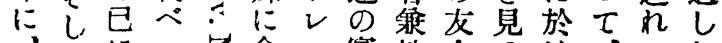

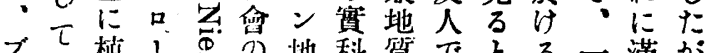

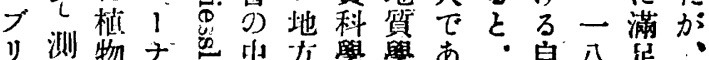

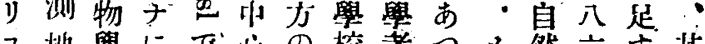
二地學にで心の校者つメ然六す其
井

\section{潜}


1 夫なるな直あつ性に庭フ

ダキれか所方接つた表園り二 リンはつにな順た。帶當にュ1 辛說無たよい應のをび該移ンス ンの理かるとなてしる植植地几

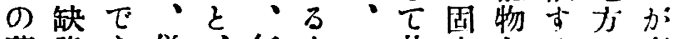

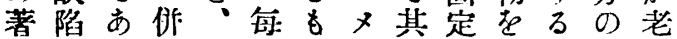
書をるしメにのンの的栽こ遠年 が滿とこン言以デ成の培と近に 出け考のデ宁外儿績戀しをかな ろし人學儿居にはは䅦て試らつ 每得 $\tau$ 說はた、・加・植 $\tau$

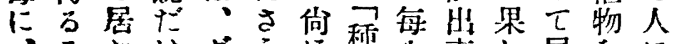

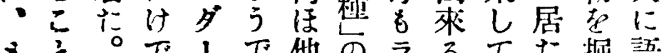
タ之。だて他のラるてた掘語

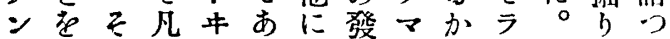
デ信してンる何生ルどマ夫取け ルしてをの○かにクうルれて所 はて彼解進同大は說かクははに

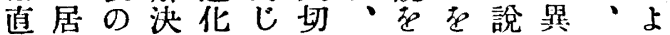
くた研し諭くなラ襄實のな頻る

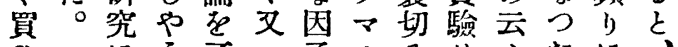
aにう否二子ルるせふてに

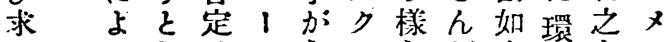
めつしはスなのな汃境存ン

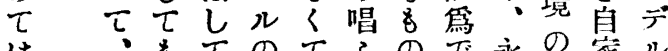

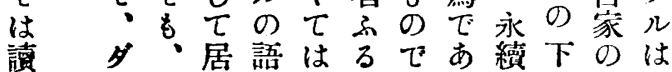

は上援てて甚紫ン ブに助居あ多䋶の リをとたつかを工 二貢在。たつ發丵 ン蔐受メか: 表學 一 二 童所居儿れ然居测 會がする。研る地 會 つ = 斯斯會・呚 長げ I のの創就師 子。不人會立中に な彼兀のの當狊任 つれは明牛時類命 ては及敏耳はのさ 居優、な研れ たれブ頭執僅究け

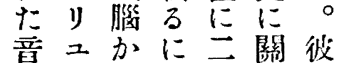

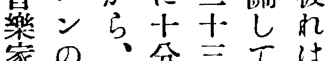
で町多な藏貢多

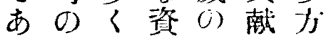
り文の格青す耐 、化激支年。 一 の 閏具學所 研 時向とへ徒加究

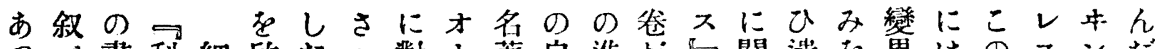

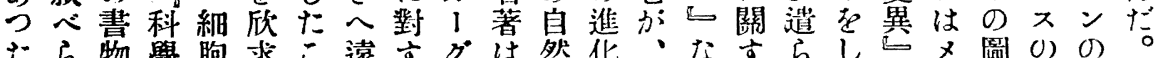

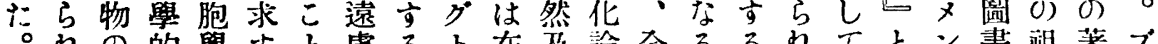

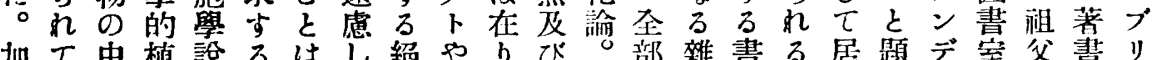

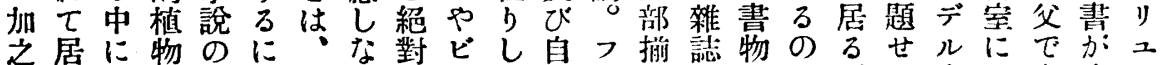
๖るは學建大メくの二昔然オつは老でる自はあ企ン

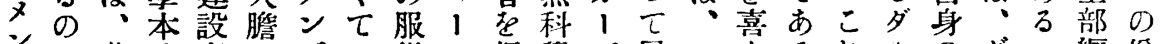
ジで花論者でデは從七偲學が居メんるれ1のダ 縓諙

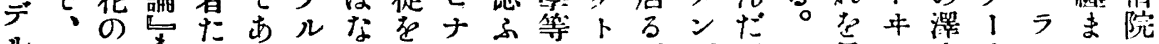

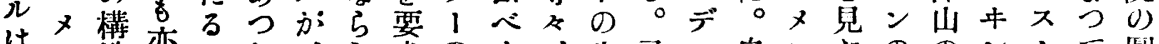
はン造亦シた、求のく、生又ル自ンたののンム泪

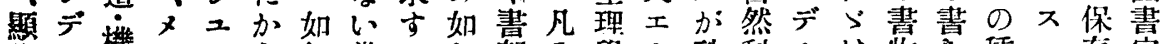

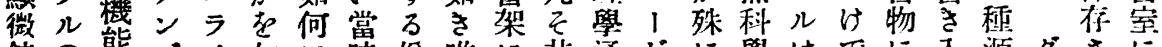
鏡の能デイ如に時俨唯に其通ゲに學はで入源ダさに

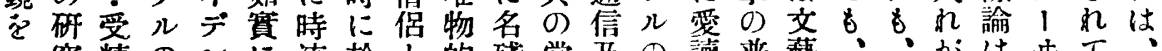

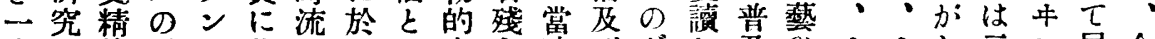

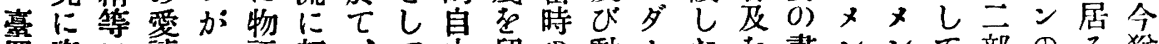

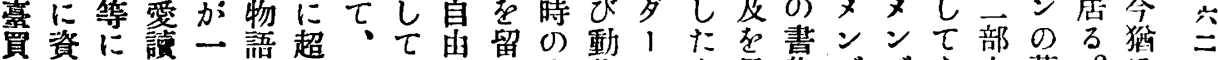

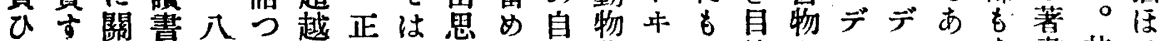

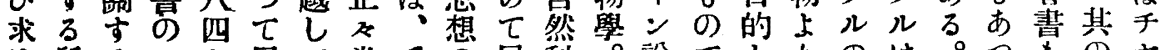
め所る一七居て堂手の居科。說でとりのは。うるのヤ て大當で年る。書る學ビ。:せち勉細又て見外 な時あに。學々能物。にュシ技る:强から出にレ

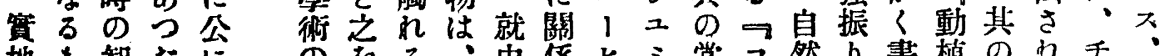

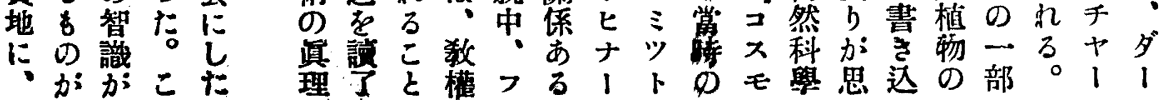




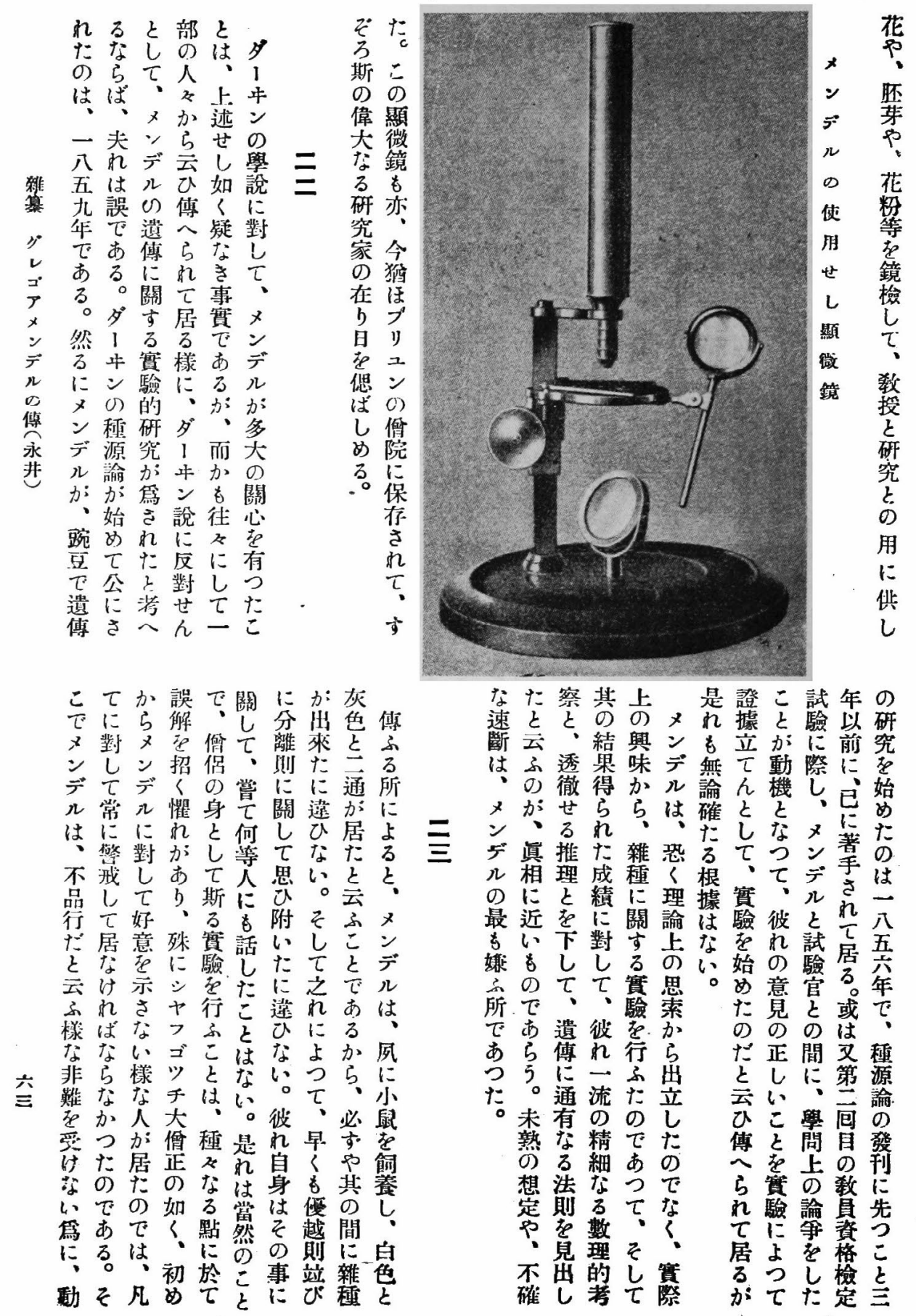


ウつ 後を完にな

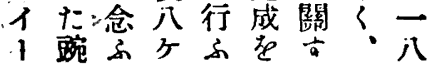
浢に年心告る當五 のに一にくげ實時六 㥧就入亘、た驗三年 植い五つ一のを十に 物て六て八で始四 學集年 六あめ歲第 會備よ踠四るた。西 於驗前のに・そン目

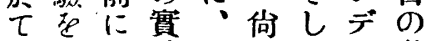
、行、驗今ほてル教 其つ彼汸二開夫は員 元七加回花れ、資 歲居・は實時は人格 にた已れ驗の・工檢 プこにたか早一交定 リと主の追晚八配試 ユはなて扣に六に驗 ン・るあさ關三よに 地一實るれし年了失 方八驗。たてに踠敗 五五材 荒四料

年 。雜至豆 乙 前驗略種 8 郎蒩 $气$ C)

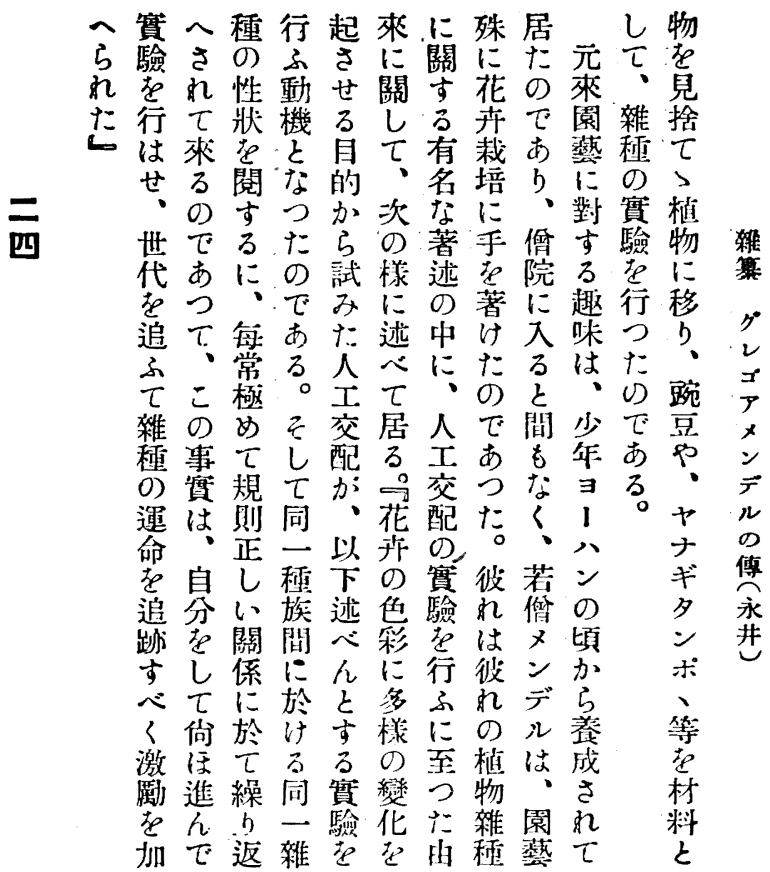

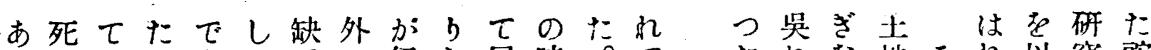

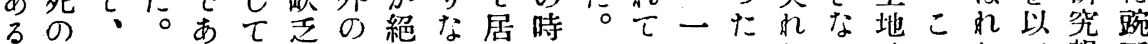
。床猶是つ.の植えくた間々か八のたいはのたて嘏豆

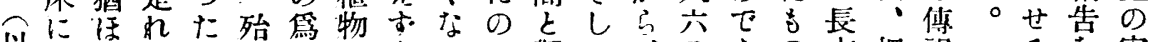

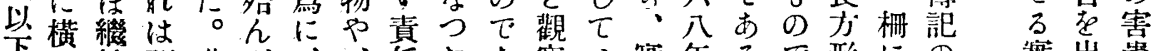

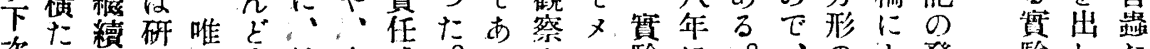
次仕せ究氣廢捗蜜感。るとン驗に。の發驗しけ

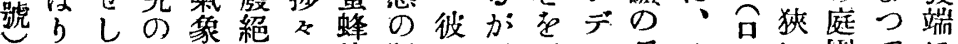

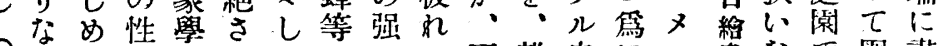

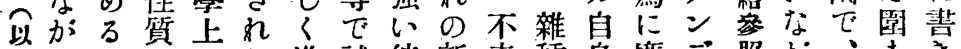

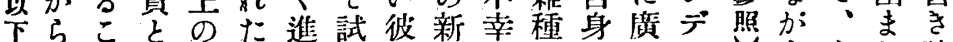

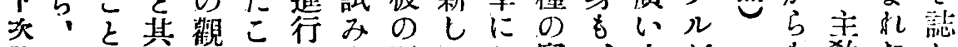

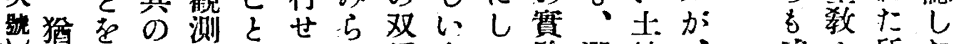

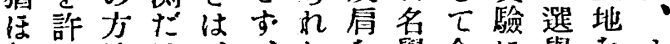

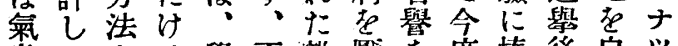

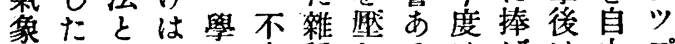
學かか:、石幸種しるはげは由プ 上ら、死のにの附位・江心の の多に雼し實け置土心是使後

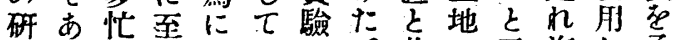

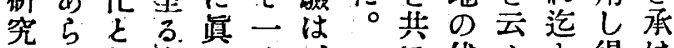

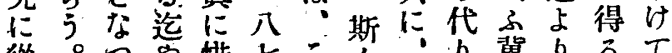

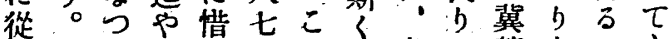

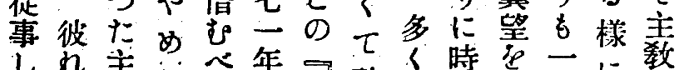

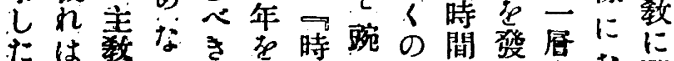

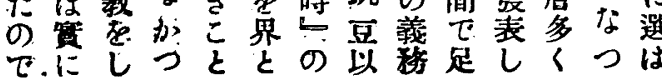

感ナ所け 謝 ツの樣 しプ、 加連 しに沿デ終加蜚 な彼子ル 了るの

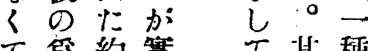

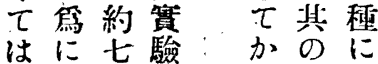
な割○疋 ら他 就 引愛坪行，後心い 广江植 $\tau$ かて㛠た行物の 慢特にン行分星 